九州大学学術情報リポジトリ

Kyushu University Institutional Repository

\title{
Bioreactor Systems for Efficient Production and Separation of Nisin Z Using Lactococcus lactis I0-1
}

Chinachoti, Noppawan

Laboratory of Microbial Technology, Department of Food Science and Technology, Faculty of Agriculture, Kyushu University

Endo, Naoyuki

Laboratory of Microbial Technology, Department of Food Science and Technology, Faculty of Agriculture, Kyushu University

Sonomoto, Kenj i

Laboratory of Microbial Technology, Department of Food Science and Technology, Faculty of Agriculture, Kyushu University

Ishizaki, Ayaaki

Laboratory of Microbial Technology, Department of Food Science and Technology, Faculty of Agriculture, Kyushu University

https://doi.org/10.5109/24231

出版情報：九州大学大学院農学研究院紀要. 42 (3/4)，pp.421-436，1998-03. Kyushu University バージョン：

権利関係: 


\title{
Bioreactor Systems for Efficient Production and Separation of Nisin Z Using Lactococcus lactis IO-1
}

\author{
Noppawan Chinachoti, Naoyuki Endo, Kenji Sonomoto \\ and Ayaaki Ishizaki \\ Laboratory of Microbial Technology, Department of Food Science and Technology, \\ Faculty of Agriculture, Kyushu University, \\ 6-10-1 Hakozaki, Higashi-ku, Fukuoka 812-8581, Japan \\ (Received August 26, 1997 and accepted December 3, 1997)
}

\begin{abstract}
Continuous fermentation was introduced to improve the nisin $\mathrm{Z}$ productivity of Lactococcus lactis IO-1. Free cells showed a good productivity at the dilution rate of $0.1 \mathrm{~h}^{-1}$. However, nisin $\mathrm{Z}$ production was affected by cell wash-out at the dilution rate of $0.2 \mathrm{~h}^{-3}$. Continuous fermentation with the cells adsorbed on ENTG-3800 gel beads displayed an improvement in productivity at higher dilution rates. No enhancement of nisin Z production was observed during continuous fermentation at a high cell density employing a hydrophobic hollow fiber membrane. The polyolefin membrane adsorbed the produced nisin $\mathrm{Z}$ too much. Continuous fermentation at a high cell density employing a ceramic membrane displayed a good nisin Z productivity at high dilution rates. Nisin Z productivity could be increased if a ceramic membrane with an adequate and effective filtration area is employed. Nisin $Z$ was separated from the fermentation broth using various kinds of adsorbents including Amberlite IR-120B, CM Sephadex C-25, Celite, and Sep-Pak cartridges. The Sep-Pak $\left(\mathrm{tC}_{18}, \mathrm{C}_{18}, \mathrm{C}_{8}\right.$, and $\left.\mathrm{tC}_{2}\right)$ cartridges showed a substantial capacity for nisin $\mathrm{Z}$ adsorption. A moderate reversed-phase column, a Sep-Pak $\mathrm{C}_{8}$ cartridge, was applied to integrate nisin $Z$ fermentation with a ceramic membrane and product separation system. Nisin $Z$ productivity was enhanced by the integration of the nisin $\mathrm{Z}$ adsorption cartridge. This result indicates the possibility of continuous fermentation with the integrated bioreactor system followed by high nisin Z productivity.
\end{abstract}

\section{INTRODUCTION}

Nisin is currently used by many manufacturers in 45 countries (Delves-Brounghton, 1990). The improvement of nisin productivity is necessary for decreasing the production cost. For increased fermentation productivity, strain improvement and process development are mostly performed. Genetic manipulation proved to be difficult and time consuming. Process development has therefore received much more attention. The improvement of reactor productivity has been reported following the application of fermenter technologies, such as continuous culture and high cell density fermentation. Continuous fermentation was investigated and has been applied to the bioreactor system in order to improve the productivity over the past several years. High cell density fermentation was applied to prevent cell wash-out which always occurs with continuous fermentation at a high dilution rate. Fermentation with high cell density was introduced using an immobilized cell system and cell recycle. The immobilized cell system was studied for many fermentative productions, such as lactic acid (Boyaval and Goulet, 1988), amino acid (Tanaka et al., 1989), ethanol (Iida et al., 1993a and b), acetonebutanol-ethanol (Gureshi and Maddox, 1995), and bacteriocin (Wan et al., 1995). For the 
cell recycle system, many modifications, such as ultrafiltration (Xavier et al., 1995), a hollow fiber membrane (Roy et al., 1982; Nagata et al., 1989; Nomura et al., 1991; Yamamoto et al., 1993; Taniguchi et al., 1994), and a ceramic membrane (Ishizaki et al., 1993) were used. With these modifications, the typical process arrangement used was in a cross-flow mode, which decreases the membrane clogging at high cell density. Cell recycling could solve the problem of cell wash-out during continuous fermentation and ease the recovery process for the products.

Many studies have indicated that most of the metabolic processes in bacteria are regulated by product accumulation (De Vuyst, 1991; De Vuyst and Vandamme, 1994; Ye et al., 1996). Like most bacterial fermentations, nisin fermentation is inhibited by lactate as well as by nisin itself (De Vuyst and Vandamme, 1994). Integrated fermentation and separation systems have been used to remove the inhibitory products, and thus to increase reactor productivity during many fermentations. Ishizaki et al. (1993) enhanced the lactate productivity of Lactococcus lactis IO-1 by continuous extraction of lactate using an electrodialyzer. They found that the extraction of lactate did not enhance lactate productivity during low glucose fermentation. The increase in lactate production was observed at high glucose concentrations. Nomura et al. (1991) have observed low lactate production, which is caused by the death of the cells that adhere to the ionexchange membrane during built-in electrodialyzer fermentation. Vongtaveesuk et al. (1994) reported an increase in lactate productivity from $\mathrm{pH}$-controlled fermentation with a microfilter module and electrodialyzer. Ye et al. (1996) reported an increase in lactate production from a multistage extraction fermentation.

Nisin has an amphiphilic character with a cluster of hydrophobic residues at the $\mathrm{N}$ terminus and hydrophilic residues at the C-terminus. The C-terminal region contains positively charged side chains. The distribuion of polar and non-polar residues over the molecular surface of nisin is suspected to be relevant to its mode of action and biological activity (Jung, 1991; De Vuyst and Vandamme, 1994). Furthermore, these characteristics were used for the basic criteria in the separation of nisin from the fermentation broth. Many researchers have evaluated various methods for nisin separation. Yang et al. (1992) reported the extraction of nisin from the fermentation broth by adsorbing nisin on the producing cells at $\mathrm{pH} 6.5$ and releasing at pH 3.0 and below. De Vuyst and Vandamme (1994) provided a brief review of nisin isolation and purification. Most of the approaches for the purification were started with a concentration step from the culture supernatant, such as precipitation with salt, precipitation with acid, or extraction with organic solvents. The following steps were various combinations of gel-filtration, ion-exchange chromatography, and reversed-phase high performance chromatography (Mulders et al., 1991; Matsusaki et al., 1996).

Recently, the adsorption of nisin on several adsorbents was studied as an approach to understand its biological activity and possible application. Daeschel et al. (1992) studied nisin activity on microorganisms that contaminated food processes. They reported that desorption of nisin from a hydrophilic silicone surface could be performed with Tween 80 . Bower et al. (1995) suggested that nisin was adsorbed in greater amount on hydrophobic surfaces than on hydrophilic ones. Joosten and Nunez (1995) observed the adsorption of nisin on polypropylene and a glass surface. The adsorption could be prevented by Tween 80. Wan et al. (1995) reported nisin adsorption ability of natural and synthetic porous 
silica compounds.

Even though many purification schemes have been published in the past, none of them are aimed at the continuous separation of nisin from the fermentation system. In the present paper, continuous nisin $\mathrm{Z}$ production by Lactococcus lactis $\mathrm{IO}-1$ was carried out with immobilized cells and cell recycle systems. Nisin Z productivity from these fermentations were compared with that of free cells. Several adsorbents were examined for nisin adsorption-desorption ability in order to construct the fermentation with a product separation system as an approach to increase productivity.

\section{MATERIALS AND METHODS}

\section{Microorganism and medium}

L. lactis IO-1 was cultivated in TGC medium without glucose (Difco Laboratories, Detroit, MI, USA) at $37^{\circ} \mathrm{C}$ for $18 \mathrm{~h}$ and was transferred to $\mathrm{CM}$ medium supplemented with $1 \%$ glucose. CM medium contained $0.5 \%$ yeast extract (Difco Laboratories, Detroit, MI, USA), $0.5 \%$ polypeptone (Nihon Seiyaku Co., Ltd., Tokyo, Japan), and $0.5 \% \mathrm{NaCl}$ in distilled water at $\mathrm{pH} 7.0$. The culture was incubated at $30^{\circ} \mathrm{C}$ and 100 strokes/min for $18 \mathrm{~h}$ as a seed culture.

\section{Continuous fermentation of $L$. lactis IO-1 cells adsorbed on photo-crosslinked resin gel beads (ENTG-3800)}

ENTG-3800 gel beads (Chinachoti et al., 1997) were sterilized by autoclaving in distilled water at $110^{\circ} \mathrm{C}$ for $10 \mathrm{~min}$. Five $\mathrm{ml}$ of the seed culture and $100 \mathrm{ml}$ of ENTG-3800 gel beads were added to $100 \mathrm{ml}$ of $\mathrm{CM}$ medium containing $4 \%$ glucose and $2 \% \mathrm{CaCO}_{3}$ for cell adsorption. The culture was incubated at $30^{\circ} \mathrm{C}$ and 100 strokes $/ \mathrm{min}$ for $24 \mathrm{~h}$. The immobilized cells obtained were further cultivated in a fresh medium for $24 \mathrm{~h}$ and then washed with sterile $0.85 \% \mathrm{NaCl}$ solution. The cell-adsorbed beads were packed into a sterile glass column $(40 \mathrm{~mm}$ i.d. $\times 200 \mathrm{~mm}$, working volume $80 \mathrm{ml})$. CM medium containing $3 \%$ glucose and $0.1 \mathrm{M} \mathrm{CaCl}_{2}$ was circulated through the column at a speed of $16 \mathrm{ml} / \mathrm{min}$. The effluent was returned back to a 500 -ml Erlenmeyer flask for controlling the $\mathrm{pH}$ at 5.5 with $5 \mathrm{~N} \mathrm{NaOH}$ (working volume, $220 \mathrm{ml}$ ). The temperature was controlled at $30^{\circ} \mathrm{C}$. Continuous fermentation was started at a dilution rate of $0.1 \mathrm{~h}^{-1}$ after the cultivation for $12 \mathrm{~h}$. The schematic diagram of this system is shown in Fig. 1.

\section{Continuous fermentation with high cell density employing hollow fiber membrane}

The fermentation was performed with $5 \%$ inoculation in a 1-L jar fermenter with $500 \mathrm{ml} \mathrm{CM}$ medium supplemented with $3 \%$ glucose and $0.1 \mathrm{M} \mathrm{CaCl}_{2}$ at $30^{\circ} \mathrm{C}$ and $320 \mathrm{rpm}$. The fermentation broth was maintained at a pH of 5.5 with $5 \mathrm{~N} \mathrm{NaOH}$. At $9 \mathrm{~h}$ of cultivation, continuous fermentation was started at a dilution rate of $0.1 \mathrm{~h}^{-1}$. At the same time the culture broth was circulated through a hollow fiber membrane (MICROZA PSP103 made of polyolefin, Asahi Kasei Co., Tokyo, Japan, fiber inner diameter: $0.7 \mathrm{~mm}, 400$ fibers, effective filtration area: $0.2 \mathrm{~m}^{2}$, pore size: $0.1 \mu \mathrm{m}$ ) at a flow rate of $120 \mathrm{ml} / \mathrm{min}$ (Nomura et al., 1991; Yamamoto et al., 1993). The permeate was pumped out at the same rate as the supply of fresh medium. The schematic diagram of this system is shown 


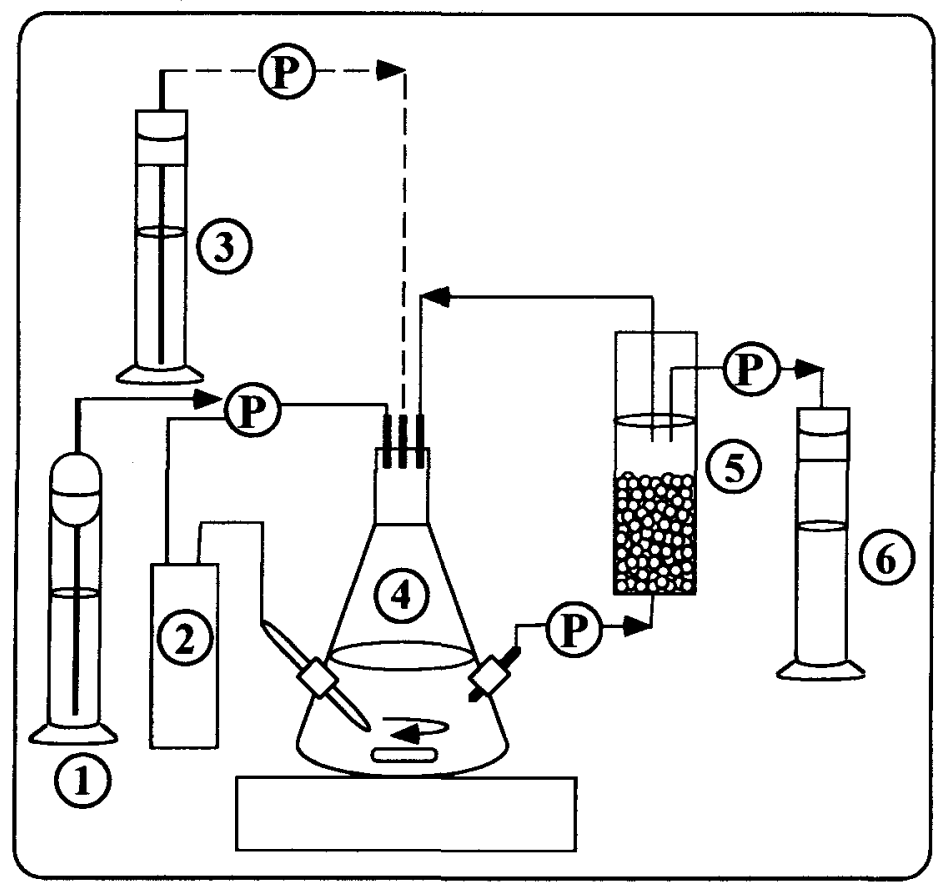

Fig. 1. Schematic diagram of continuous fermentation with Lactococcus lactis IO-1 cells immobilized on photo-crosslinked gel beads (ENTG-3800).
(1) $3 \mathrm{~N} \mathrm{NaOH}$ reservoir
(2) $\mathrm{pH}$ controller
(3) Fresh medium reservoir
(4) Mixing reservoir for $\mathrm{pH}$ control
(5) Packed-bed reactor
(6) Product reservoir

Symbol: (p) pump

in Fig. 2.

\section{Continuous fermentation with high cell density employing ceramic membrane}

The 1-L jar fermenter was filled with $500 \mathrm{ml}$ of CM medium supplemented with $3 \%$ glucose and $0.1 \mathrm{M} \mathrm{CaCl}_{2}$. Five percent of the seed culture was inoculated. The fermentation was performed at $30^{\circ} \mathrm{C}$ and $320 \mathrm{rpm}$ with the $\mathrm{pH}$ controlled at 5.5. Continuous fermentation and cell filtration were simultaneously started after the cultivation for $9 \mathrm{~h}$ with a dilution rate of $0.1 \mathrm{~h}^{-1}$. The fermentation broth was circulated through a ceramic membrane (Biott Co., Ltd., Tokyo, Japan, material: alumina, external diameter: $10 \mathrm{~mm}$, internal diameter: $8 \mathrm{~mm}$, length: $200 \mathrm{~mm}$, effective filtration area: $50.2 \mathrm{~cm}^{2}$, average diameter of fine holes: $0.2 \mu \mathrm{m}$ ) (Ishizaki et al., 1993) with a flow rate of $120 \mathrm{ml} / \mathrm{min}$. The permeate was separated out at the same rate as the feed medium. The 


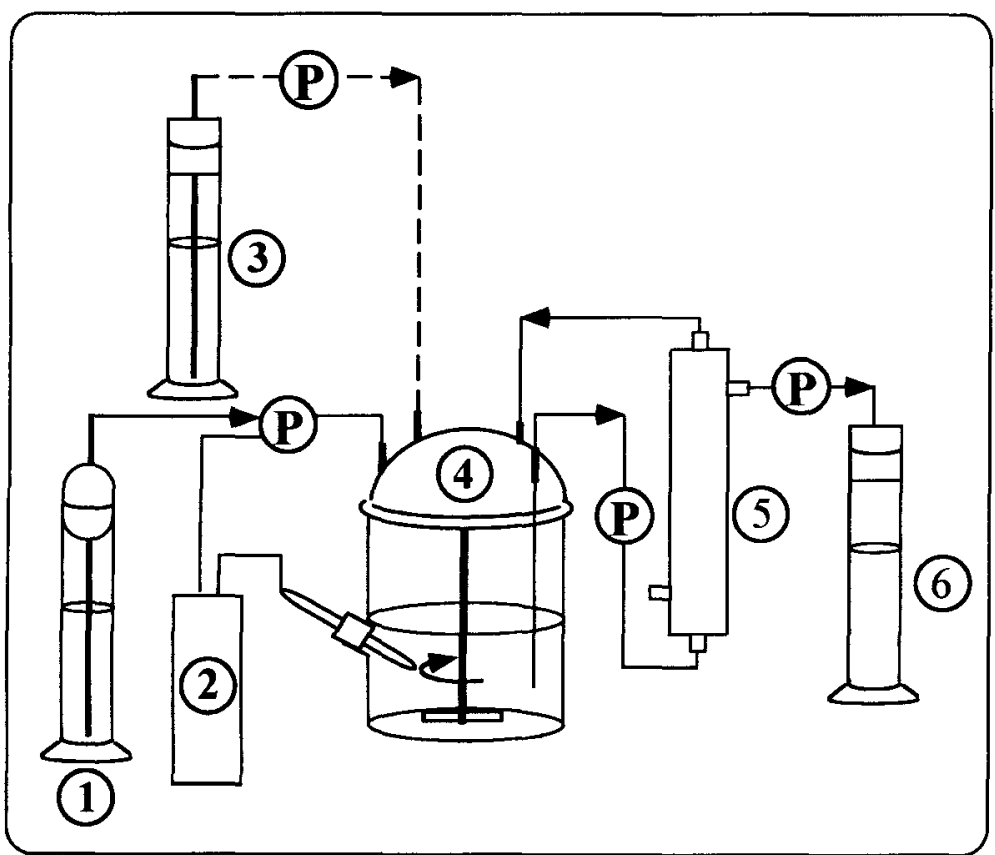

Fig. 2. Shematic diagram of continuous fermentation of Lactococcus lactis IO1 with microfilter membrane module.
(1) $3 \mathrm{~N} \mathrm{NaOH}$ reservoir
(2) $\mathrm{pH}$ controller
(3) Fresh medium reservoir
(4) Fermenter
(5) Microfilter module
(6) Permeate reservoir

Symbol: (p) pump

dilution rate was changed to $0.2 \mathrm{~h}^{-1}$ and $0.3 \mathrm{~h}^{-1}$ at the seventh and eleventh hour after the continuous operation had started, respectively. The feed medium consisted of the same components as the initial medium. The schematic diagram of this system is the same as in Fig. 2 except the hollow fiber membrane was replaced by a ceramic membrane.

\section{Nisin preparation}

Five percentage of $L$. lactis $10-1$ was inoculated in $300 \mathrm{ml}$ of $\mathrm{CM}$ medium supplemented with $3 \%$ glucose. The culture was incubated at $30^{\circ} \mathrm{C}$ and $320 \mathrm{rpm}$ for $6-12 \mathrm{~h}$. The $\mathrm{pH}$ was controlled at 5.5. The cells were removed from the fermentation broth by centrifugation at $17,800 \times \mathrm{g}$ for $15 \mathrm{~min}$ at $4^{\circ} \mathrm{C}$. The supernatant was used in the subsequent nisin $\mathrm{Z}$ adsorption experiment. 


\section{Adsorbents}

The adsorbents used were reversed-phase mini-cartridges, Sep-Pak tC $\mathrm{CC}_{18}\left[-\mathrm{SiC}_{18} \mathrm{H}_{37}\right], \mathrm{C}_{18}$ [-Si $\left.\left(\mathrm{CH}_{3}\right)_{2} \mathrm{C}_{18} \mathrm{H}_{37}\right], \mathrm{C}_{8}\left[-\mathrm{Si}\left(\mathrm{CH}_{3}\right)_{2} \mathrm{C}_{8} \mathrm{H}_{17}\right]$, and $\mathrm{tC}_{2}\left[-\mathrm{SiC}_{2} \mathrm{H}_{5}\right]$ ) from Waters Co. (Milford, MA, USA), CM-Sephadex C-25 (Pharmacia Biotech, Uppsala, Sweden), Amberlite IR-120B (Orugano Co., Tokyo, Japan), and Celite No. 535 (Wako Pure Chemical Industries, Ltd., Osaka, Japan).

\section{Adsorption methods}

Celite was soaked in distilled water overnight before being used. Amberlite IR-120B was treated with $12 \mathrm{~N} \mathrm{HCl}$ and washed with $20 \mathrm{mM}$ acetate buffer until the $\mathrm{pH}$ reached 3.6. CM-Sephadex C-25 was swelled and boiled in $20 \mathrm{mM}$ acetate buffer ( $\mathrm{pH} \mathrm{3.6)}$ for $2 \mathrm{~h}$. Each adsorbent was packed in a column with a bed volume of $5 \mathrm{ml}$. The Sep-Pak cartridge columns used possessed $1 \mathrm{ml}$ of bed volume. The broth supernatant containing a known concentration of nisin $Z$ was applied to the column at a flow rate of $1 \mathrm{ml} / \mathrm{min}$. Nisin $Z$ activity was measured before and after the broth was passed through the column.

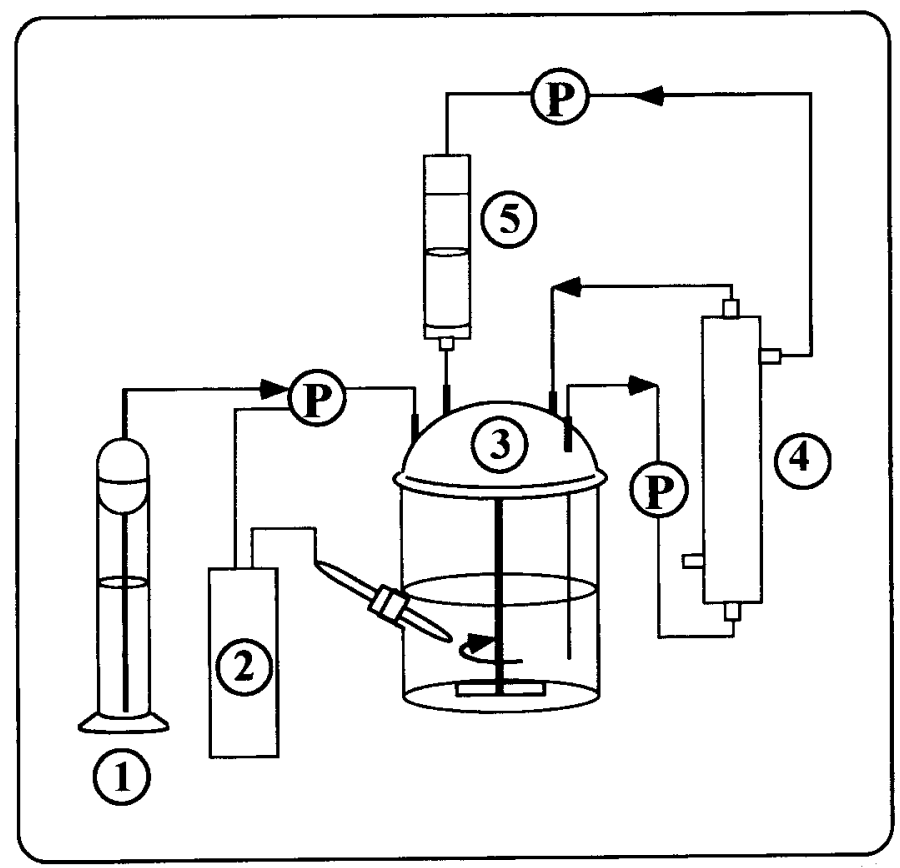

Fig. 3. Schematic diagram of batch fermentation process with ceramic membrane coupled with Sep-Pak $\mathrm{C}_{8}$ cartridge.
(1) $3 \mathrm{~N} \mathrm{NaOH}$ reservoir
(2) $\mathrm{pH}$ controller
(3) Fermenter
(4) Ceramic membrane
(5) Sep-Pak $\mathrm{C}_{8}$ cartridge

Symbol: (p) pump 


\section{Batch fermentation employing a ceramic membrane}

Five percent of the preculture was inoculated in $500 \mathrm{ml} \mathrm{CM}$ medium supplemented with $3 \%$ glucose and $0.1 \mathrm{M} \mathrm{CaCl}_{2}$. The fermentation was performed at $30^{\circ} \mathrm{C}$ and $320 \mathrm{rpm}$. The $\mathrm{pH}$ was controlled at 5.5. The fermentation broth was circulated through a ceramic membrane from the beginning of the cultivation period at a flow rate of $120 \mathrm{ml} / \mathrm{min}$. The rate of permeate was $0.83 \mathrm{ml} / \mathrm{min}$.

\section{Batch fermentation employing ceramic membrane coupled with Sep-Pak $\mathrm{C}_{8}$ cartridge as a nisin $Z$ separation column}

The fermentation was done in the similar manner as already described except for the following treatment of the permeate. The permeate was applied to the Sep-Pak $\mathrm{C}_{8}$ cartridge ( $35 \mathrm{ml}$ bed volume, Waters Co.) at a flow rate of $0.83 \mathrm{ml} / \mathrm{min}$ and the effluent was returned back to the fermenter. The schematic diagram of this system is shown in Fig. 3.

\section{Analytical methods}

The assays for dry cell weight (DCW), glucose, lactate and nisin Z were performed as previously reported (Chinachoti et al., 1997).

\section{RESULTS}

\section{Continuous fermentation of $L$. lactis IO-1 adsorbed on ENTG-3800}

Continuous fermentation of the free cells displayed a good cell growth followed by a high nisin $\mathrm{Z}$ productivity at a dilution rate of $0.1 \mathrm{~h}^{-1}$. However, cell growth, lactate and nisin $\mathrm{Z}$ production were observed to rapidly decrease when the dilution rate was increased to $0.2 \mathrm{~h}^{-1}$ (data not shown).

In the immobilized cell system, cell mass that leaked from the beads was lower than that in the free cell fermentation and seemed to gradually decrease with cultivation time (Fig. 4). Stable production of lactate was obtained in the range of $20-25 \mathrm{~g} / \mathrm{l}$-fermentation broth. Produced nisin Z displayed a high level in the range of $1500-2900 \mathrm{AU} / \mathrm{ml}$. Nisin Z production remained at a high level even when a decrease in cell leakage was observed. Almost all the glucose was utilized during the continuous fermentation. At the dilution rates of $0.2 \mathrm{~h}^{-1}$ and $0.3 \mathrm{~h}^{-1}$, nisin $\mathrm{Z}$ and lactate were moderately produced with some fluctuations (data not shown). Nisin $\mathrm{Z}$ productivities at the dilution rates of $0.2 \mathrm{~h}^{-1}$ and $0.3 \mathrm{~h}^{-1}$ were higher than that of the free cells (Table 1 ).

\section{Continuous fermentation of nisin $Z$ with high cell density employing hollow fiber membrane}

Cell density increased with the continuous fermentation and the cell recycle (Fig. 5). As a consequence, the lactate concentration was higher than $30 \mathrm{~g} / l$. On the contrary, nisin $\mathrm{Z}$ in the broth was rapidly decreased after $9 \mathrm{~h}$ of cultivation when cell recycling was allowed to start and finally became nearly constant at $300 \mathrm{AU} / \mathrm{ml}$. Furthermore, no nisin Z was detected in the permeate from the hollow fiber module. After the continuous fermentation, the cells were aseptically harvested and used for batch fermentation with a fresh medium. As a result, the production of nisin $\mathrm{Z}$ was $1300 \mathrm{AU} / \mathrm{ml}$. 
According to these results, nisin $\mathrm{Z}$ produced might be adsorbed on the hydrophobic hollow fiber membrane made of polyolefin. Actually, the culture broth containing $2120 \mathrm{AU} / \mathrm{ml}$ of nisin $\mathrm{Z}$ was circulated through the hollow fiber membrane at $120 \mathrm{ml} / \mathrm{min}$, which resulted in no nisin $\mathrm{Z}$ activity in the broth within $30 \mathrm{~min}$ of operation.

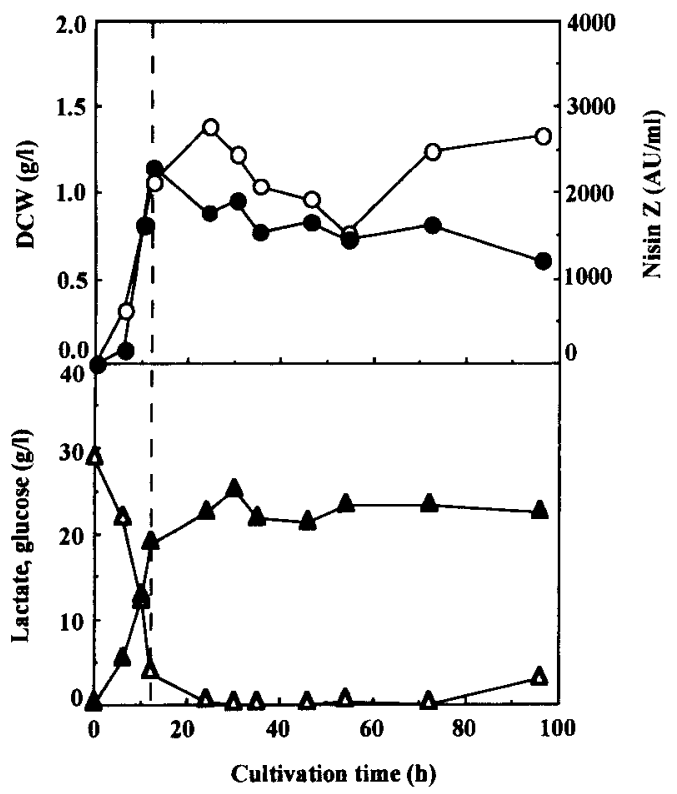

Fig. 4. Continuous fermentation of Lactococcus lactis IO-1 cells immobilized on photo-crosslinked resin gel beads (ENTG-3800). Continuous fermentation was started at $12 \mathrm{~h}$ as indicated by the dotted line. The dilution rate was maintained at $0.1 \mathrm{~h}^{-1}$. The same volume of fresh CM medium with $3 \%$ glucose and $0.1 \mathrm{M} \mathrm{CaCl}_{2}$ as the filtrate was supplied. $\mathrm{pH}$ was maintained at 5.5 .

Symbols: Dry cell weight (DCW), $\bigcirc$ nisin $\mathrm{Z}, \boldsymbol{\wedge}$ lactate, $\triangle$ glucose

Table 1. Comparison of nisin Z productivities between ENTG-3800-adsorbed cells and free cells in continuous fermentation

\begin{tabular}{|c|c|c|c|c|c|c|}
\hline $\begin{array}{c}\text { Dilution } \\
\text { rate } \\
\mathrm{D} \\
\left(\mathrm{h}^{-1}\right) \\
\end{array}$ & $\begin{array}{c}\text { Average } \\
\text { glucose } \\
\text { consumed } \\
\mathrm{S} \\
(\mathrm{g} / l) \\
\end{array}$ & $\begin{array}{c}\text { Average } \\
\text { nisin } \mathrm{Z} \\
\mathrm{P} \\
\left(\times 10^{5} \mathrm{AU} / l\right)\end{array}$ & $\begin{array}{c}\text { Average } \\
\text { L-lactate } \\
\text { L } \\
(\mathrm{g} / \mathrm{l})\end{array}$ & $\begin{array}{c}\text { Average } \\
\text { free cells } \\
\mathrm{X} \\
(\mathrm{g} / \mathrm{l})\end{array}$ & $\begin{array}{c}\text { Nisin } \mathrm{Z} \\
\text { productivity } \\
\mathrm{PD} \\
\left(\times 10^{5} \mathrm{AU} \cdot l^{-1} \cdot \mathrm{h}^{-1}\right)\end{array}$ & $\begin{array}{c}\text { Nisin } Z \\
\text { yield } \\
\text { P/S } \\
\left(\times 10^{4} \mathrm{AU} / \mathrm{g}\right)\end{array}$ \\
\hline \multicolumn{7}{|c|}{ Free cells } \\
\hline 0.1 & 27.9 & 2.81 & 23.3 & 1.310 & 2.81 & 10.0 \\
\hline \multicolumn{7}{|c|}{$\begin{array}{l}\text { ENTG-3800- } \\
\text { adsorbed sells }\end{array}$} \\
\hline 0.1 & 27.0 & 2.16 & 23.3 & 0.618 & 2.16 & 8.00 \\
\hline 0.2 & 25.1 & 1.86 & 18.6 & 0.940 & 3.71 & 7.40 \\
\hline 0.3 & 24.7 & 1.30 & 13.3 & 0.630 & 3.89 & 5.26 \\
\hline
\end{tabular}




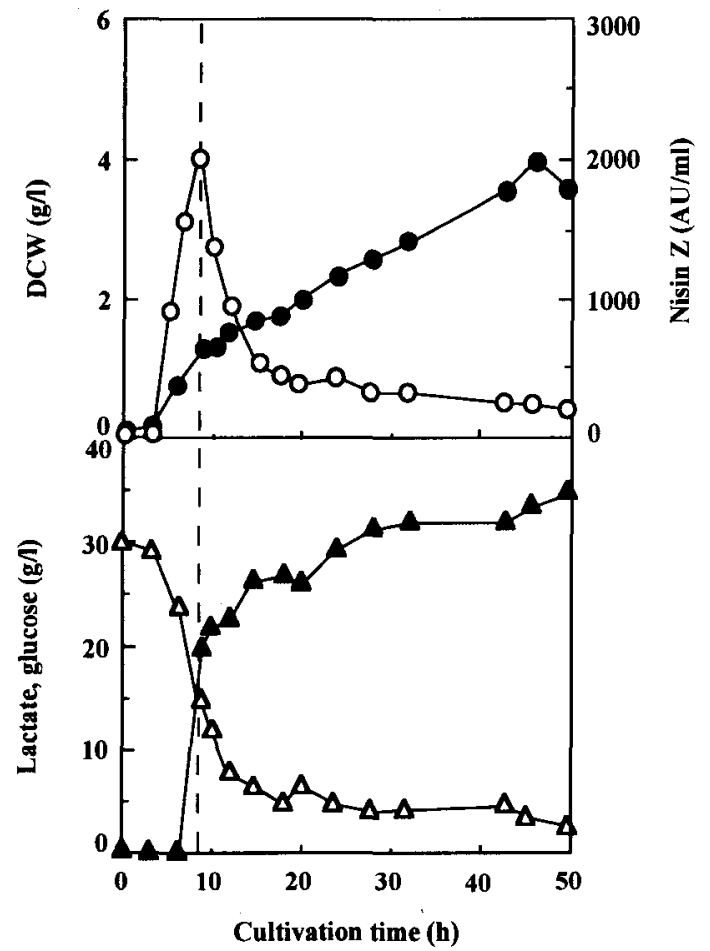

Fig. 5. High cell density continuous fermentation of Lactococcus lactis IO-1 with a hollow fiber membrane. Continuous fermentation was started at $9 \mathrm{~h}$ as indicated by the dotted line. The dilution rate was maintained at $0.1 \mathrm{~h}^{-1}$. The same volume of fresh $\mathrm{CM}$ medium with $3 \%$ glucose and $0.1 \mathrm{M} \mathrm{CaCl} \mathrm{Cl}_{2}$ as the filtrate was supplied. $\mathrm{pH}$ was maintained at 5.5 .

Symbols: Dry cell weight (DCW), $\bigcirc$ nisin $\mathrm{Z}$ in the broth, $\boldsymbol{\Delta}$ lactate, $\triangle$ glucose

\section{Continuous fermentation employing the ceramic membrane}

To enhance nisin $Z$ productivity, a ceramic membrane was applied to serve high cell density fermentation of $L$. lactis IO- 1 . Continuous fermentation started after $9 \mathrm{~h}$ of cultivation. DCW gradually increased while residual glucose was in a very low concentration (Fig. 6). Lactate was produced at a constant level and nisin Z was significantly produced throughout the cultivation. No difference in nisin $\mathrm{Z}$ concentration was observed between the broth and the permeate. The increase in the dilution rate hardly affected the profile of cell growth, glucose residue, lactate and nisin $\mathrm{Z}$ production. At the dilution rate of $0.3 \mathrm{~h}^{-1}$, DCW reached $3.3 \mathrm{~g} / l$ while the clogging of the ceramic membrane was observed. 


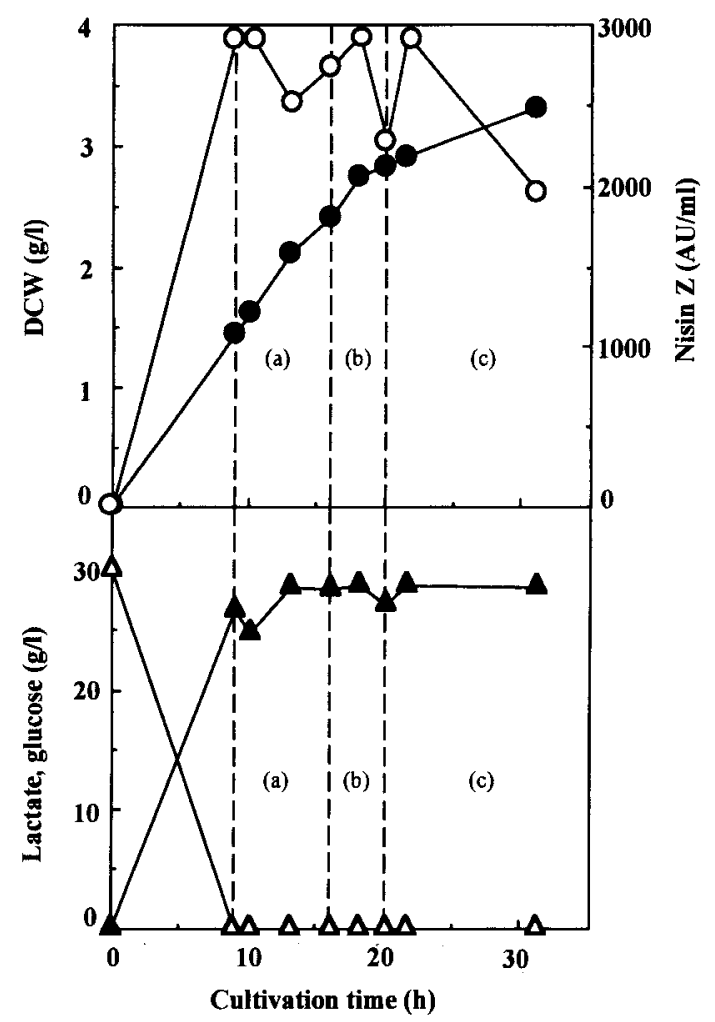

Fig. 6. High cell density continuous fermentation of Lactococcus lactis IO-1 with a ceramic membrane. Continuous fermentation was started at $9 \mathrm{~h}$, $16 \mathrm{~h}$ and $22 \mathrm{~h}$ as indicated by the dotted lines at a dilution rate of (a) $0.1 \mathrm{~h}^{-1}$, (b) $0.2 \mathrm{~h}^{-1}$ and (c) $0.3 \mathrm{~h}^{-1}$, respectively. The same volume of fresh $\mathrm{CM}$ medium with $3 \%$ glucose and $0.1 \mathrm{M} \mathrm{CaCl}_{2}$ as the filtrate was supplied. $\mathrm{pH}$ was maintained at 5.5 .

Symbols: Dry cell weight (DCW), $\bigcirc$ nisin $\mathrm{Z}$ in the broth, $\mathbf{A}$ lactate, $\triangle$ glucose

\section{Adsorption of nisin $\mathrm{Z}$ with various kinds of adsorbents}

Nisin Z was adsorbed on several adsorbents at room temperature. The nisin Z adsorption capacity of these materials is shown in Table 2. Nisin $Z$ was effectively adsorbed on the Sep-Pak $\mathrm{tC}_{18}$ cartridge. The adsorption capacity was found to depend on the hydrophobicity of the materials under the condition described above. Celite was stirred in $50 \mathrm{ml}$ of the culture supernatant, which could not be passed through the dense column of Celite. Amberlite IR-120B and CM-Sephadex C-25 showed a lower nisin Z adsorption capacity than the Sep-Pak cartridges. 
Table 2. Adsorption of nisin $\mathrm{Z}$ on various kinds of adsorbents

\begin{tabular}{|c|c|c|c|c|c|}
\hline \multirow[t]{2}{*}{ Adsorbents } & \multirow{2}{*}{$\begin{array}{l}\text { Nisin Z applied } \\
(A U / m)\end{array}$} & \multirow{2}{*}{$\begin{array}{c}\text { Nisin Z in filtrate } \\
(\mathrm{AU} / \mathrm{ml})\end{array}$} & \multirow{2}{*}{$\begin{array}{l}\text { Adsorption } \\
(\%)\end{array}$} & \multicolumn{2}{|l|}{ Adsorption capacity } \\
\hline & & & & (AU/mg-adsorbents) & $(\%)$ \\
\hline Sep-Pak tC ${ }_{2}$ & 2380 & 1400 & 41.3 & 39.3 & 41.2 \\
\hline Sep-Pak $\mathrm{C}_{8}$ & 2380 & 222 & 62.8 & 59.8 & 63.7 \\
\hline Sep-Pak $C_{18}$ & 2380 & 152 & 74.6 & 71.0 & 74.5 \\
\hline Sep-Pak tC 18 & 2380 & 0 & 100 & 95.3 & 100 \\
\hline Amberlite IR-120B & 3780 & 2930 & 22.4 & 4.05 & 4.25 \\
\hline CM-Sephadex C-25 & 3780 & 3010 & 40.2 & 6.20 & 6.50 \\
\hline Celite No. 535 & 2550 & 1970 & 22.8 & 29.0 & 30.4 \\
\hline
\end{tabular}

\section{Desorption of nisin $Z$ from the adsorption column}

Amberlite IR-120B and CM-Sephadex C-25 colums were washed with 2 bed volumes of $20 \mathrm{mM}$ acetate buffer $(\mathrm{pH} 3.6)$. The columns were then eluted with the buffer with stepwise increasing sodium chloride concentrations from $0.2 \mathrm{M}$ to $1.2 \mathrm{M}$. The desorption solutions were applied through the column at a flow rate of $1 \mathrm{ml} / \mathrm{min}$. Amberlite IR-120B displayed a higher nisin Z desorption than CM-Sephadex C-25. Nisin was also eluted with the buffers of low ionic strengths.

Nisin $\mathrm{Z}$ adsorbed on the Sep-Pak $\mathrm{tC}_{18}$ cartridge was attempted to be detached using several desorption solutions. As a result, $80 \%$ acetonitrile with $0.05 \%$ trifluoroacetic acid (TFA) was the only desorption solvent among the solvents tested which showed an insufficient desorption. No release of nisin $Z$ from the column was observed using surfactants such as sodium dodecyl sulfate (SDS) and Tween 80. On the other hand, nisin $\mathrm{Z}$ adsorbed on Sep-Pak $\mathrm{C}_{18}$ and $\mathrm{C}_{8}$ cartridges was eluted by $80 \%$ acetonitrile without TFA, which resulted in $34 \%$ and $37 \%$ of nisin $Z$ desorption, respectively. No nisin $Z$ was eluted from the $\mathrm{Sep}-\mathrm{Pak} \mathrm{tC}_{2}$ cartridge by the treatment. Elution with stepwise increasing acetonitrile concentration gave a satisfactory recovery of nisin $\mathrm{Z}$ from the Sep-Pak $\mathrm{C}_{8}$ cartridge.

\section{Batch fermentation employing ceramic membrane}

To observe in detail the effect of the ceramic membrane on the production of nisin $\mathrm{Z}$, batch fermentation employing a ceramic membrane was performed. The fermentation profile is illustrated in Fig. 7. The cells grew logarithmically for $9 \mathrm{~h}$ of the initial fermentation. Glucose was at a very low level at $12 \mathrm{~h}$. The final cell concentration was about $1.4 \mathrm{~g} / \mathrm{l}$. Nisin $\mathrm{Z}$ activity increased with cell growth. Nisin $\mathrm{Z}$ activity in the permeate, which passed through ceramic membrane, was the same value as that in the fermented broth (data not shown).

\section{Batch fermentation employing a ceramic membrane coupled with the Sep-Pak $\mathrm{C}_{8}$ cartridge}

The effect of the Sep-Pak $\mathrm{C}_{8}$ cartridge column as a nisin $\mathrm{Z}$ separator on the whole nisin Z productivity was investigated. Figure 8 depicts the fermentation profile of the integrated bioreactor system. Specific growth rate and maximum cell mass were higher with the cartridge than without one. With the Sep-Pak $C_{8}$ cartridge, the rate of nisin $Z$ 


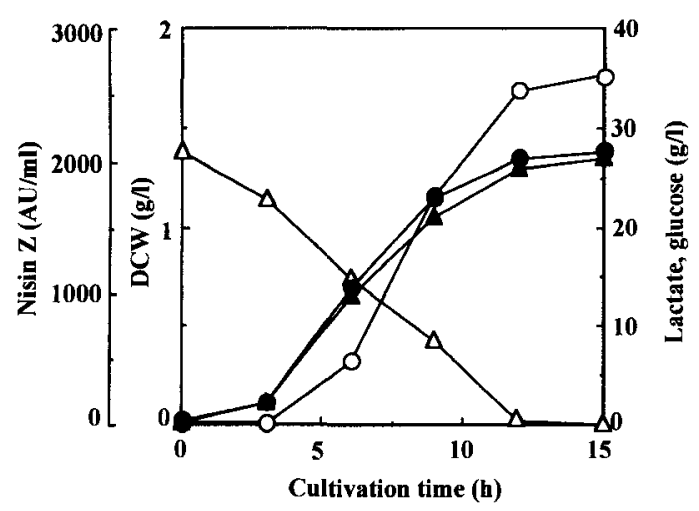

Fig. 7. Batch fermentation of Lactococcus lactis IO-1 employing ceramic membrane. The fermentation was performed in $\mathrm{CM}$ medium supplemented with $3 \%$ glucose and $0.1 \mathrm{M} \mathrm{CaCl}^{2}$ at $30{ }^{\circ} \mathrm{C}$ and $\mathrm{pH} 5.5$.

Symbols: Dry cell weight (DCW), $\bigcirc$ nisin $\mathrm{Z}, \boldsymbol{\Delta}$ lactate, $\Delta$ glucose

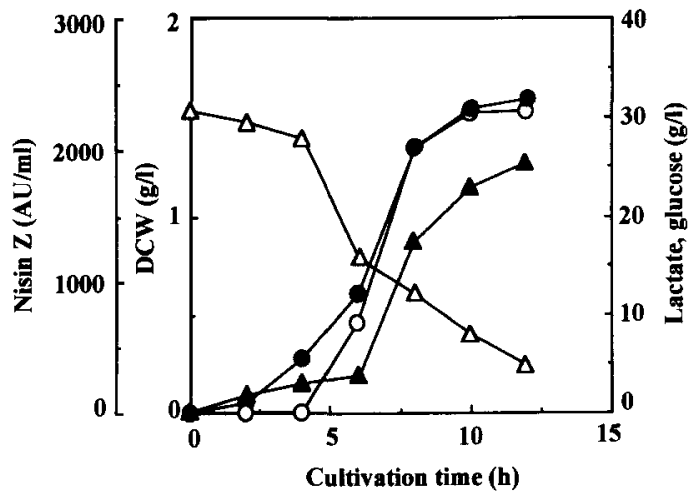

Fig. 8. Batch fermentation of Lactococcus lactis IO-1 cells employing ceramic membrane coupled with Sep-Pak $\mathrm{C}_{8}$ cartridge. The fermentation was performed in $\mathrm{CM}$ medium supplemented with $3 \%$ glucose and $0.1 \mathrm{M}$ $\mathrm{CaCl}_{2}$ at $30^{\circ} \mathrm{C}$ and $\mathrm{pH} 5.5$.

Symbols: Dry cell weight (DCW), $\bigcirc$ nisin $\mathrm{Z}, \boldsymbol{\Delta}$ lactate, $\Delta$ glucose

production was also higher than without the cartridge. No nisin $\mathrm{Z}$ activity was detected in the effluent through the Sep-Pak $\mathrm{C}_{8}$ cartridge. The calculated amount of nisin $\mathrm{Z}$ adsorbed on the cartridge throughout $12 \mathrm{~h}$ of cultivation was $6.9 \times 10^{5} \mathrm{AU}$. Nisin $\mathrm{Z}$ productivity of the integrated bioreactor system was $2 \times 10^{6} \mathrm{AU} / \mathrm{system}$ for $12 \mathrm{~h}$ of fermentation. 


\section{DISCUSSION}

A continuous fermentation was performed to enhance the nisin $\mathrm{Z}$ productivity of the systems. With the free cells, DCW was constantly remained at a high value throughout the operation at the dilution rate of $0.1 \mathrm{~h}^{-1}$. The high DCW value resulted in a high nisin productivity. Nisin Z productivity at the dilution rate of $0.1 \mathrm{~h}^{-1}$ was $2.81 \times 10^{5} \mathrm{AU} \cdot l^{-1} \cdot \mathrm{h}^{-1}$ (Table 1). However, the increase in dilution rate from $0.1 \mathrm{~h}^{-1}$ to $0.2 \mathrm{~h}^{-1}$ provided a decrease in cell density. The cell wash-out led to the low production of lactate and nisin $\mathrm{Z}$.

Many researchers reported an improvement in productivity by increasing the cell density (Major and Bull, 1989; De Vuyst and Vandamme, 1994; Martin et al., 1994). In the present paper, cell immobilization and cell recycle techniques were employed in order to avoid cell wash-out and enhance the productivity.

In the immobilized cell system, nisin Z production by the cells adsorbed on ENTG3800 somewhat fluctuated (Fig. 4). This might be due to improper mixing of the culture broth inside the column containing the immobilized cells. As the column contained a high density of cells, the rapid consumption of glucose led to a rapid decrease in $\mathrm{pH}$. The $\mathrm{pH}$ of the culture broth in the column might be different from that in the $\mathrm{pH}$-controlled flask. The flow rate at $16 \mathrm{ml} / \mathrm{min}$ might be too low to allow good mixing in the column. The nisin $\mathrm{Z}$ productivities of the immobilized cell system at the dilution rates of $0.1 \mathrm{~h}^{-1}, 0.2 \mathrm{~h}^{-1}$, and $0.3 \mathrm{~h}^{-1}$ were $2.16 \times 10^{5} \mathrm{AU} \cdot l^{-1} \cdot \mathrm{h}^{-1}, 3.71 \times 10^{5} \mathrm{AU} \cdot l^{-1} \cdot \mathrm{h}^{-1}$, and $3.89 \times 10^{5} \mathrm{AU} \cdot l^{-1} \cdot \mathrm{h}^{-1}$, respectively (Table 1).

Zezza et al. (1993) reported the lower level of nisin production in the batch culture of immobilized cells compared to the batch culture of free cells. Huang et al. (1996) reported the higher pediocin productivity during continuous fermentation of immobilized cells than that of free cells because of the higher dilution rate. Their results were the same as the results presented in this paper. The low productivity of immobilized cells systems was suggested to be dependent on the factors, such as limitation of product diffusion into the medium, increased adsorption of the product on the cell surfaces and inhibition of product biosynthesis in the local environment of the immobilized cells. The same results were reported by Cho et al. (1996). They stated that pediocin productivity during continuous fermentation with immobilized cells was likely to be greater than that with free cells at a high dilution rate in rich media. Wan et al. (1995) stated a higher bacteriocin productivity with the continuous fermentation of immobilized cells than that with the batch fermentation of free cells. Thus the continuous fermentation of immobilized cells enhanced the nisin Z productivity when a higher dilution rate was applied.

Continuous fermentation with a high cell density employing a hollow fiber membrane was reported to improve nisin productivity (Taniguchi et al., 1994). In the present paper, nisin $\mathrm{Z}$ was produced at a low level (Fig. 5). However, during batch fermentation with a high density of cells harvested after the continuous fermentation, an increase in nisin $\mathrm{Z}$ production was observed. This indicated that the cells in the fermenter still have the capability to produce nisin $\mathrm{Z}$. The possibility to adsorb nisin $\mathrm{Z}$ on the hydrophobic hollow fiber membrane made of polyolefin was tested and the results revealed that nisin $Z$ was easily adsorbed on the membrane. The elution of the adsorbed nisin $Z$ with $1 \%$ SDS resulted in the degradation of nisin $\mathrm{Z}$. 
A ceramic membrane which made from alumina hardly adsorbed nisin $\mathrm{Z}$, so it was used for cell recycling in the continuous fermentation. The ceramic membrane assisted in a high cell density in the reactor which resulted in the complete utilization of glucose (Fig. 6). Nisin $\mathrm{Z}$ productivities achieved by the continuous fermentation were $2.60 \times$ $10^{5} \mathrm{AU} \cdot l^{-1} \cdot \mathrm{h}^{-1}$ and $5.60 \times 10^{5} \mathrm{AU} \cdot l^{-1} \cdot \mathrm{h}^{-1}$ at the dilution rates of $0.1 \mathrm{~h}^{-1}$ and $0.2 \mathrm{~h}^{-1}$, respectively. However, the effective filtration area of the ceramic membrane was too small to assist in a high cell density at the higher dilution rates. The membrane was clogged at the cell concentration of $3.3 \mathrm{~g} / l$ and the dilution rate of $0.3 \mathrm{~h}^{-1}$. To achieve a higher nisin $\mathrm{Z}$ productivity, the effective filtration area of the ceramic membrane should be increased or a more efficient instrument for cell separation, such as vortex filtration (Ishizaki et al., 1993) be used.

The nisin Z adsorption capacity of Amberlite IR-120B and CM-Sephadex C-25 was lower than those of the Sep-Pak cartridges, whose adsorption mode is a hydrophobic interaction (Table 2). Nisin Z was tightly bound via a hydrophobic interaction. The SepPak $\mathrm{tC}_{18}$ cartridge showed the highest nisin $Z$ adsorption ability. The hydrophobic interaction between $\mathrm{tC}_{1 \times}$ and the nisin $\mathrm{Z}$ molecule was not influenced by surfactants, such as $1 \%$ SDS and $1 \%$ Tween 80 . Nisin $Z$ was insufficiently desorbed from the Sep-Pak $\mathrm{tC}_{18}$ cartridge even by using $80 \%$ acetonitrile with $0.05 \%$ TFA. Although the Sep-Pak $\mathrm{C}_{18}$ and $\mathrm{C}_{8}$ cartridges showed a lower nisin $\mathrm{Z}$ adsorption than $\mathrm{tC}_{18}$, nisin $\mathrm{Z}$ could be desorbed with $80 \%$ acetonitrile without $0.05 \%$ TFA. Furthermore, nisin Z was eluted from the Sep-Pak $\mathrm{C}_{8}$ cartridge with $30 \%$ acetonitrile. It was likely that the high nisin $\mathrm{Z}$ adsorption resulted in the low desorption. Daeschel et al. (1992) suggested that when the nisin adsorption on hydrophobic surfaces was occurred, the desorption was low. Thus the Sep-Pak $\mathrm{C}_{8}$ adsorbents, which showed a moderate adsorption-desorption ability for nisin $Z$, was selected for further experimentation.

The objective of operating an integrated fermentation with a ceramic membrane and product recovery system is to remove inhibitory products and allow the complete utilization of the sugar substrate. The product recovery system may simplify the purification step. This paper reports the preliminary observation for the possibility of enhancing the productivity when the product recovery system, a Sep-Pak $\mathrm{C}_{8}$ cartridge as the nisin $\mathrm{Z}$ adsorption column, was integrated. Cell growth was higher in the fermentation with the integrated bioreactor system than without a separation system. This revealed that the carbon source and essential other nutrients for cell growth were not adsorbed on the Sep-Pak $\mathrm{C}_{8}$ cartridge. Moreover, the separation of inhibitory product, nisin Z, from the system allowed a high cell density and consequently a high specific production rate of nisin $\mathrm{Z}$. Thus, nisin $\mathrm{Z}$ productivity of the system after $12 \mathrm{~h}$ of incubation was $2 \times 10^{6} \mathrm{AU} / \mathrm{system}$ which was higher than that of the fermentation without the $\mathrm{C}_{8}$ cartridge $\left(1.2 \times 10^{6} \mathrm{AU} /\right.$ system $)$. These results suggested the possibility of continuous fermentation with the integrated bioreactor system followed by high nisin $\mathrm{Z}$ productivity.

\section{REFERENCES}

Bower, C. K., Mcquire, J. and M. A. Daeschel 1995 Suppression of Listeria monocytogenes colonization following adsorption of nisin onto silica surfaces. Appl. Environ. Microbiol., 61: 992-997

Boyaval, P. and J. Goulet 1988 Optimal conditions for production of lactic acid from cheese whey 
permeate by calcium alginate entrapped Lactobacillus helveticus. Enzyme Microb. Technol., 10 725-728

Chinachoti, N., Sonomoto, K., A. Ishizaki 1997 Immobilization of Lactococcus lactis IO-1 for nisin Z production. J. Fac. Agr., Kyushu Univ., 42: 151-169

Cho, H. Y., Yousef, A. E. and S. T. Yang 1996 Continuous production of pediocin by immobilized Pediococcus acidilactici PO2 in a packed-bed bioreactor. Appl. Microbiol. Biotechnol, 45: 589-594

Daeschel, M. A., Mcguire, J. and H. Al-Makhlafi 1992 Antimicrobial activity of nisin adsorbed to hydrophilic and hydrophobic silicon surfaces. J. Food Prot., 55: 731-735

De Vuyst, J. 1991 Microbial manipulation of nisin biosynthesis and fermentation. In "Nisin and novel lantibiotics", ed. by G. Jung and H. -G. Sahl, ESCOM Science Publishers B. V., Leiden, pp. 397-409

De Vuyst, L. and E. J. Vandamme 1994 Nisin, a lantibiotic produced by Lactococcus lactis subsp. lactis: properties, biosynthesis, fermentation and applications. In "Bacteriocins of lactic acid bacteria", ed. by L. de Vuyst and E. J. Vandamme, Blackie Academic and Professional, Glasgow, pp. 151-221

Delves-Brounghton, J. 1990 Nisin and its use as a food preservative. Food Technol., 44: 100-117

Gureshi, N. and I. S. Maddox 1995 Continuous production of acetone-butanol-ethanol using immobilized cells of Clostridium acetrobutylicum and integration with product removal by liquid-liquid extraction. J. Ferment. Bioeng., 80: 185-189

Huang, L., Lacroix, C., Daba H. and R. E. Simard 1996 Pediocin 5 production and plasmid stability during continuous free and immobilized cell cultures of Pediococcus acidilactici UL5. J. Appl. Bacteriol., 80: $635-644$

lida, T., Izumida, H., Akagi Y. and M. Sakamoto 1993a Continuous ethanol fermentation in molasses medium using Zymomonas mobilis immobilized in photo-crosslinkable resin gels. J. Ferment. Bioeng.,75: $32-35$

lida, T., Sakamoto, M., Izumida, H. and Y. Akagi 1993b Characteristics of Zymomonas mobilis immobilized by photo-crosslinkable resin in ethanol fermentation. J. Ferment. Bioeng., 75: 28-31

Ishizaki, A., Takasaki, S. and Y. Furuta 1993 Cell recycled fermentation of glutamate using a novel crossflow filtration system with constant air supply. J. Ferment Bioeng., 76: 316-320

Joosten, H. M. L. J. and M. Nunez 1995 Adsorption of nisin and enterocin 4 to polypropylene and glass surfaces and its prevention by Tween 80. Lett. in Appl. Microbiol., 21: 389-392

Jung, G. 1991 Lantibiotics: a survey in nisin and novel lantibiotics. In "Nisin and novel lantibiotics", ed. by G. Jung and H. -G. Sahl, ESCOM Science Publishers B. V., Leiden, pp. 1-34

Major, N. C. and A. T. Bull 1989 The physiology of lactate production by Lactobacillus delbreukii a chemostat with cell recycle. Biotechnol. Bioeng., 34: 592-599

Martin, R. S., Bushell, D., Leak, D. J. and B. S. Hartley 1994 Cultivation of L-lactate dehydrogenase mutant of Bacillus stearothermophilus in continuous culture with cell recycle. Biotechnol. Bioeng., 44: $21-28$

Matsusaki, H., Endo, N., Sonomoto, K. and A. Ishizaki 1996 Development of purification method and identification of a peptide antibiotic produced by Lactococcus lactis IO-1. Food Sci. Technol., Int., 2: $157-162$

Mulders, J. W. M., Boerrigter, I. J., Rollema, H. S., Siezen, R. J. and W. M. de Vos 1991 Identification and characterization of the lantibiotic nisin Z, a natural variant. Eur. J. Biochem., 201: 581-584

Nagata, N., Herouvis, K. J., Dziewulski, D. M. and G. Belfort 1989 Cross-flow membrane microfiltration of a bacterial fermentation broth. Biotechnol. Bioeng., 34: 447-466

Nomura, Y., Yamamoto, K. and A. Ishizaki 1991 Factors affecting lactic acid production rate in the builtin electrodialyzer fermentation. An approach to high speed batch culture. J. Ferment. Bioeng., 71: 450-452

Roy, T. B. V., Blanch, H. W. and C. R. Wilke 1982 Lactic acid production by Lactococcus delbreuckii in a hollow fiber fermenter. Biotechnol. Lett., 4: 483-488

Tanaka, T., Yamamoto, K., Towprayoon, S., Nakajima, H., Sonomoto, K.,Yokozeki, K., Kubota, K. and A. Tanaka 1989 Continuous production of L-serine by immobilized growing Corynebacterium glycinophilum cells. Appl. Microbiol. Biotechnol, 30: 564-568

Taniguchi, M., Hoshino, K., Urasaki, H. and M. Fujii 1994 Continuous production of an antibiotic polypeptide (Nisin) by Lactococcus lactis using a bioreactor coupled to a microfiltration module. $J$. Ferment. Bioeng., 77: 706-708

Vonktaveesuk, P., Tonokawa, M. and A. Ishizaki 1994 Stimulation of the rate of L-lactate fermentation 
using Lactococcus lactis IO-1 by periodic electrodialysis. J. Ferment. Bioeng, 77: 508-512

Wan, J., Hickey M. W. and M. J. Coventry 1995 Continuous production of bacteriocins, brevicin, nisin, and pediocin using calcium alginate immobilized bacteria. J. Appl. Bacteriol, 79: 671-676

Xavier, A. M. R. B., Gonclaves, L. M. D., Moreina, J. L. and M. J. T. Carrondo 1995 Operational patterns affecting lactic acid production in ultrafiltration cell recycle bioreactor. Biotechnol. Bioeng., 45: 320327

Yamamoto, K., Ishizaki, A. and P. F. Stanbury 1993 Reduction in the length of the lag phase of L-lactate fermentation by the use of inocula from electrodialysis seed culture. J. Ferment. Bioeng., 76: 151152

Yang, R., Johnson, M. C. and B. Ray 1992 Novel method to extract large amounts of bacteriocins from lactic acid bacteria. Appl. Environ. Microbiol, 50: 3355-3359

Ye, K., Jin, S. and K. Shimizu 1996 Performance improvement of lactic acid fermentation by multistage extractive fermentation. J. Ferment. Bioeng., 81: 240-246

Zezza, N., Pasini, G., Lombardi, A., Mercenier, A., Spettoli, P., Zamorani, A. and M. P. Nuti 1993 Production of a bacteriocin active on lactate fermenting clostridia by Lactococcus lactis subsp. lactis immobilized in coated alginate beads. J. Dairy Res., 60: 581-591 